ITAS-NEWS

\section{Projektgruppe „,Technikfolgen- abschätzungen zur Nanotech- nologie" des ITAS nimmt ihre Arbeit auf}

Nanotechnologie erfreut sich in den letzten Jahren eines wachsenden forschungspolitischen Interesses und einer regen öffentlichen Aufmerksamkeit. Nicht zuletzt die möglich erscheinende Herstellung, Strukturierung und „Manipulation“ von Materialien auf atomarer und molekularer Ebene und damit verbunden die Kontrolle von makroskopischen - ggf. neuen - Funktionalitäten und Produkteigenschaften sowie die weitere Miniaturisierung von Komponenten, Produkten und Verfahren bis hin zum Bau von „Nanomaschinen“ sind für Teile von Wissenschaft und Wirtschaft wie auch für potenzielle Kunden faszinierend. Die öffentliche Wahrnehmung der Nanotechnologie ist gegenwärtig vor allem von spektakulären, aber wissenschaftlich bislang wenig fundierten und - wenn überhaupt - kaum in absehbarer Zeit realisierbaren Anwendungen geprägt. Die bereits umgesetzten bzw. kurz- und mittelfristig zu erwartenden nanotechnologiebasierten Produkte und Verfahren und deren Chancen und Risiken bleiben hingegen in der öffentlichen Diskussion, letztgenanntes auch in der Fachdiskussion, weitgehend unbeachtet. Dabei bieten sich gerade auch hier zahlreiche, nicht nur im Hinblick auf TA-relevante Fragestellungen interessante Forschungsaufgaben.

Mit Beginn des Jahres 2003 hat ITAS eine Projektgruppe „Technikfolgenabschätzungen zur Nanotechnologie" gebildet, die sich - zusammen mit weiteren Instituten des Forschungszentrums Karlsruhe und externen Partnern - mit einigen nanotechnologie-bezogenen TA-Fragestellungen detaillierter befassen wird. Die Projektgruppe wird von Torsten Fleischer geleitet, weitere Mitarbeiter des ITAS sind Dr. Michael Decker und Dr. Ulrich Fiedeler.

Die geplanten Arbeiten können entlang von drei Leitthemen gruppiert werden:
Technische Entwicklungen im Materialund Verfahrensbereich und ihre Implikationen: Ein wesentliches Anwendungsfeld von Nanotechnologie wird im Bereich der Materialien und Werkstoffe und damit verbundenen Verfahrenstechniken liegen. Dadurch werden Innovationsund Substitutionsprozesse angestoßen, die in ihrer Reichweite bislang kaum überschaubar sind, aber von z.T. erheblicher technischer, wirtschaftlicher, ökologischer und sozialer Relevanz sein können. Ausgehend von einer Analyse und Beobachtung der technischen Entwicklung in diesem Bereich sollen vor allem mögliche nichttechnische Folgen technischer Entwicklungen identifiziert und teilweise auch vertieft analysiert werden. Dazu zählen unter anderem Auswirkungen einer verbreiteten Nutzung von nanotechnologiebasierten Materialien und Verfahren auf Gesundheit und Umwelt oder strukturwandelnde Prozesse infolge von umfangreicheren Materialsubstitutionen und damit verbundene ökonomische und soziale Effekte, letztlich auch Beiträge der Nanotechnologie zu einer nachhaltigen Entwicklung. Verbunden damit sind erste Arbeitsschritte für Beiträge zur Erstellung von „ökologischen Bilanzen“ von nanotechnologiebasierten Materialien, die längerfristig in Lebenszyklusanalysen von daraus gefertigten Produkten münden könnten, die Analyse bestehender bzw. die Erarbeitung neuer Konzepte zur Vorsorge bei erkannten technischen, gesundheitlichen oder ökologischen Risiken (neue Rezyklierungs- oder Verwertungskonzepte, Arbeitsschutz, Freisetzung) sowie das Benennen von Forschungs- und ggf. auch schon Regelungsbedarf.

Nanotechnologie als ,enabling technology": Viele Weiterentwicklungen bei bekannten Produkten und Techniken, vor allem aber auch neuartige Produkt- und Prozessinnovationen werden auf nanotechnologiebasierten Materialien, Komponenten oder Verfahren beruhen. Zugleich werden weniger die Materialien und Techniken selbst als vielmehr ihre Nutzung in neuen Produkten oder Techniken und deren Anwendung in bestehenden oder neuen Kontexten beträchtliche ökonomische, ökologische, soziale und institutionelle Konsequenzen haben. Dabei zeichnen sich schon heute zahlreiche Anwendungen $a b$, zu deren Realisierung Nanowissenschaften oder Nanotechnologie wichtige Beiträge leisten sollen. 
Von besonderem Interesse sind dabei Entwicklungen an der Nahtstelle von Physik, Chemie und Biologie. Diese bieten zahlreiche viel versprechende Anwendungen, etwa in der Medizin, der Landwirtschaft oder Informationsverarbeitung, bergen aber auch nicht zu unterschätzende Problempotenziale. Ein Schwerpunkt der Arbeiten soll darum bei der Rolle der Nanotechnologie für Konzepte liegen, die eine Verknüpfung technischer und biologischer Systeme zum Ziel haben. Aufgabe von Vorhaben in diesem Kontext soll es sein, Trends in Forschung und Entwicklung und damit verbundene Produktund Anwendungsvisionen zu identifizieren; darzustellen, welche davon technisch und ökonomisch viel versprechend sind bzw. hohe Problemlösungspotenziale besitzen, und offen zu legen, wo Risikopotenziale und diesbezüglicher Untersuchungsbedarf vermutet werden bzw. gesellschaftlicher Diskussionsbedarf - nicht zuletzt auch um damit verbundene ethische Fragestellungen - herrschen könnte.

Nanotechnologie als Herausforderung für die Weiterentwicklung der TA-Methodik: Nanotechnologie befindet sich auf vielen Teilgebieten noch in einer frühen Phase ihrer Entwicklung. Grundlagenarbeiten dominieren, Produkt- und Anwendungsideen existieren wenn überhaupt - erst in groben Umrissen. Dies bringt erhebliche methodische Herausforderungen für TA-Arbeiten mit sich. Das - zu einem so frühen Zeitpunkt unter hoher Unsicherheit gewonnene - TA-relevante Wissen und seine Bewertung sollen Teil von Entscheidungen werden, die bereits im Vorfeld oder am Anfang eines FuE-Projektes getroffen werden. Zugleich bietet dies aber auch neue Chancen. Ein Ziel vieler TA-Konzepte ist es bekanntlich, bereits in den frühen Phasen der Technikentwicklung mitzuwirken, den dann potenziell größeren Gestaltungsmöglichkeiten (für die Wirtschaft wie auch für die Politik) eine fundiertere Grundlage zu verschaffen und vor dem Erreichen eines ,point of no return“ zu den entwicklungsbegleitenden Entscheidungsprozessen beitragen zu können. Letztlich geht es um die richtige Balance bei der Frage: „Wie früh ist zu früh, wie spät ist zu spät?“

Aufgabe von Vorhaben in diesem Kontext soll sein, am Beispiel der Nanotechnologie aufzuzeigen, inwieweit TA und ihre Methoden zur Technikgestaltung in diesem Bereich beitragen können bzw. gegebenenfalls weiterzuentwickeln sind. Hierzu wären u. a. Potenziale der Nanotechnologie, etwa in Bezug auf Beiträge zur Lösung erkennbarer ökologischer oder Nachhaltigkeits-Probleme und diesbezügliche Gestaltungs-, Förder- oder Steuerungsmöglichkeiten, aufzuzeigen. Ausgehend von anwendungsspezifischen Problemlagen und Handlungserfordernissen wären Ziele von wissenschaftlichtechnischer Entwicklungstätigkeit zu bestimmen und daraus Hinweise dafür zu gewinnen, inwieweit absehbare Entwicklungen auf dem Gebiet der Nanotechnologie hierzu Lösungen oder Lösungsbeiträge liefern könnten. Sich abzeichnende wissenschaftlich-technische oder ökonomisch bedingte Innovationshindernisse könnten identifiziert und Vorschläge zu ihrer Beseitigung ausgearbeitet werden. Dies kann zum einen dazu dienen, die Entwicklung von nanotechnologiebasierten Produkten und Verfahren unter den vielfältigen techno-ökonomischen Kriterien wie auch unter nichttechnischen Aspekten zielgenauer zu machen. Zum anderen könnten Förderstrategien für Nanotechnologie-Vorhaben zielgenauer auf deren Problemlösungsbeiträge ausgerichtet werden.

(Torsten Fleischer)

Ein weiterer Beitrag des Autors zu dem Thema TA und Nanotechnologie, der sich in ausführlicherer Form mit inhaltichen und konzeptionellen Fragen von TA-Studien in diesem Bereich befasst, ist in Heft 3/4 2002, S. $111-123$, der TA-TuP zu finden.

\section{Understanding and Bench- marking ICT-Developments in EU and Candidate Countries. EU-Projects "MAB" and "Tigers" with ITAS Participation}

ITAS is involved in two related EU projects. One is "Monitoring and Benchmarking" (MAB) the so-called "eEurope+ 2003 Action Plan" in the EU Candidate Countries. The other project is the "Tigers" project which addresses causes for success or failure of ICT-related developments in the present EU member states, with the ultimate objective of drawing conclu 
sions regarding policies for the Candidate Countries. The importance of these policies cannot be underestimated, as we talk about the accession of 13 countries with about 170 million inhabitants (Estonia, Latvia, Lithuania, Poland, Czech Republic, Slovakia, Hungary, Slovenia, Cyprus, Malta, Romania, Bulgaria, and Turkey).

Both projects are performed within the framework of the European Science and Technology Observatory (ESTO). They are sponsored by the ICT unit of the Institute for Prospective Technological Studies (IPTS) in Seville, Spain, which is part of the European Union's Joint Research Centre.

\section{Project MAB}

The MAB project started in early 2002 and is currently in its final stage of evaluation. It is sponsored by IPTS, led by ITAS, with TNO from the Netherlands as partner. Background of the MAB project are the European Union's "eEurope 2002 Action Plan" and the "eEurope+ 2003 Action Plan" containing plans for similar actions in the Candidate Countries.

The "eEurope 2002 Action Plan" was designed to contribute to the European Union's objective "to become the most competitive and dynamic knowledge-based economy in the world capable of sustainable economic growth with more and better jobs and greater social cohesion", as agreed at the European Council in 2000 ("Lisbon Summit"). The plan aims at bringing Europe closer to meeting these objectives and contains for instance actions for making Internet use cheaper, for educating people how to use the Internet and for encouraging citizens to use it at school, at home and at the workplace.

The "eEurope+ 2003 Action Plan" contains a number of modifications for adapting it to the situation of the Candidate Countries, e.g., actions on telecom liberalisation and on the implementation of EU regulations.

The objectives of the MAB project were basically (1) to analyse the quality of data gathering and benchmarking activities in the current EU-countries, and (2) to address the problems of gathering such data in the Candidate Countries.

The benchmarking efforts which took place in the "EU-15" countries led to the gath- ering of data in fields such as Internet access, use of computers at school, and government on-line services. In order to rapidly and regularly obtain comparative results, the European Commission had subcontracted data gathering activities to consultancy companies.

The analysis of documents and expert interviews revealed that there are some issues with the current data gathering activities which should be addressed in the future. For instance, regarding the definition of indicators, items such as Internet access via "cable modem" should be defined in detail. Also, the way in which the interviews to collect data for these indicators were conducted could be improved, for instance all interviewers should be trained in a consistent way in all countries. In addition, all survey methods should be made available so that the interested public would be in a position to judge the results. The latter would, for example, allow to understand how in the e-government statistics a differentiation is made between a "two-way interaction", a "transaction" and a "delivery".

Regarding the Candidate Countries, expert interviews led to the conclusion that certain other issues will need to be taken into account, too, such as how foreigners and emigrants are to be counted in order to create a representative sample. In addition, it was found that it will not be possible to easily conduct representative surveys using telephone interviews, as they are common in West European countries, since large shares of the population do not have a fixed line phone.

It was concluded that while it makes sense for public reports to provide only key results, the complete methodological information, definitions, questionnaires etc. should be made available to interested citizens and experts, for example as links on the WWW. The provision of such methodological information will hopefully also explain any apparent contradiction to the results of other surveys. Furthermore, any data gathering effort should be done in close co-operation with experts in the field. The Commission is already "moving" their data gathering efforts into such directions, for example by intensifying co-operation with the National Statistical Institutes and by working on a refined list of indicators.

MAB not only addressed methodological issues of data collection, but also the benefits 
of the current benchmarking exercise. Interviewed experts in the Candidate Countries expressed concern about the lack of competitiveness of their countries and about emerging social problems. They pointed to the need for political support, for example, for ICT production. This suggests that indicators which measure progress towards achieving the Lisbon objectives - competitiveness, social cohesion, and sustainability - would be useful. Taking these aspects into account would be welcomed as a substantial improvement for eEurope to measure Information Society development.

\section{References}

In the MAB project, the benchmarking efforts related to the following plans were analysed:

- eEurope 2002 Action Plan: http://europa.eu.int/information_society/ee urope/action_plan/pdf/actionplan_en.pdf

- eEurope+ 2003 Action Plan: $\mathrm{http}$ ://europa.eu.int/information_society/int ernational/candidate_countries/ action_plan/index_en.htm

Official European Commission benchmarking reports are:

- eEurope Benchmarking Report, 2002. $\operatorname{COM}(2002) 62$ final. 5 February 2002: $\mathrm{http}: / /$ europa.eu.int/information_society/ eeurope/news_library/documents/ index_en.htm

- eEurope+ 2003 Progress Report, 2002 (Report prepared by the EU Membership Candidate Countries with the assistance of the European Commission; Brussels): http://europa.eu.int/information society/topics/international/regulatory/ eeuropeplus/index_en.htm

Draft ESTO reports produced are:

- Weber, Arnd; Wehn de Montalvo, Uta; van Audenhove, Leo; Křżž, Pavel: Data Gathering for eEurope and eEurope+ Indicators. Expert Survey on Feasibility. Karlsruhe, Delft 2002

- Weber, Arnd; Wehn de Montalvo, Uta: eEurope+ Indicators. Expert Survey on the Suitability of Indicators. Karlsruhe, Delft 2002
Please contact ITAS, TNO or IPTS if you are interested in the results of the MAB project:

- Marc Bogdanowicz, IPTS: M.Bogdanowicz@jrc.es

- Jean Claude Burgelman, IPTS: jean-claude.burgelman@jrc.es

- Arnd Weber, ITAS: arnd.weber@itas.fzk.de

- Uta Wehn de Montalvo, TNO: wehndemontalvo@stb.tno.nl

\section{Project Tigers}

The Tigers project is also an ESTO project sponsored by IPTS. The project is led by MERIT, the Maastricht Economic Research Institute on Innovation and Technology (The Netherlands). Other partners are the Austrian Research Centers, Atlantis Consulting (Greece), The Circa Group (Ireland), and ITAS. The project started in August 2002 and will be completed in 2003 .

The objectives of the Tigers project are to analyse West-European cases of successful and less successful ICT-related developments, with the ultimate goal of using this knowledge when creating policies for the Candidate Countries.

ITAS is responsible for the analysis of the development of the semiconductor production firms in the Dresden region. The most wellknown companies located in that region are Infineon, producing, e.g., memory chips, and AMD, producing in particular microprocessors. First results show that it has been possible to develop a world-class semiconductor production cluster in that region. The investment decisions after re-unification were substantially influenced by the available skills of engineering scientists and operators, who had acquired these skills when producing semiconductors in the former GDR. The cluster is growing faster in terms of employment than expected. The sustainability of this development and its meaning for the Candidate Countries will be investigated, essentially through expert interviews.

The project partners analyse ICT-related developments in Austria, Flanders, and Greece. Also the "Celtic Tiger" of IT development in Ireland will be investigated, hence the name of the project. Results of the project are planned to be published in Spring 2003. 
For further information on the project please consult the following Web address:

http://tigers.infonomics.nl

(Arnd Weber, ITAS; Uta Wehn de Montalvo, TNO)

।

\section{Abschluss des HGF-Projekts „Zukunftsfähigkeit"“ - Projekt- präsentation in Berlin}

Das seit 1999 laufende Projekt „Global zukunftsfähige Entwicklung - Perspektiven für Deutschland" der Helmholtz-Gemeinschaft (vgl. hierzu das Schwerpunktthema im Heft 1/2000 der TA-Datenbank-Nachrichten und den Beitrag von Armin Grunwald im Heft 2/2001) ist abgeschlossen. Dieses Projekt wurde von ITAS federführend geleitet; beteiligt waren darüber hinaus das Forschungszentrum Jülich mit der Programmgruppe Mensch, Umwelt, Technik (MUT) und der Programmgruppe Systemforschung und technologische Entwicklung (STE), das Deutsche Zentrum für Luft- und Raumfahrt durch das Institut für Verkehrsforschung und die Abteilung Systemanalyse und Technikbewertung sowie das Fraunhofer-Institut für Autonome Intelligente Systeme (AiS) und das Fraunhofer-Institut für Rechnerarchitektur und Softwaretechnik.

Ein zusammenfassender Bericht über die Ergebnisse des Projekts ist in Vorbereitung und wird im Mai in der Reihe „Global zukunftsfähige Entwicklung - Perspektiven für Deutschland" bei Edition Sigma, Berlin, erscheinen. Daneben sind eine Reihe weiterer Projektpublikationen in Vorbereitung. Auf einer öffentlichen Präsentation werden am 26./27. Mai 2003 in Berlin die wesentlichen Ergebnisse der dreijährigen Forschungsarbeit vorgestellt und mit Teilnehmern aus Wissenschaft, Politik und Öffentlichkeit diskutiert (siehe hierzu den Veranstaltungshinweis in diesem Heft, S. 162f.).

\section{Dritte Tagung des ITAS zu Glo- balem Wandel am 3. - 4. Juli 2003 in Berlin}

Mit dem dritten Symposium des ITAS zu Globalem Wandel unter dem Titel „Vom Wissen zum Handeln? Die Forschung zum Globalen Wandel und ihre Umsetzung" setzt ITAS eine Tradition von Tagungen fort, auf denen bereits 1999 (Transsektorale Forschung zum Globalen Wandel) und 2000 (Integrative Modellierung zum Globalen Wandel) bestimmte Aspekte der Forschung zum Globalen Wandel thematisiert wurden. Diese dritte Tagung befasst sich mit der Frage, wie Ergebnisse erkenntnisorientierter Forschung in politische oder allgemein-gesellschaftliche Handlungsstrategien umgesetzt werden können. Auf der Tagung soll dargestellt und diskutiert werden, wie es um die Umsetzung steht, wie die Umsetzung dieser Forschungsleistungen verbessert werden kann und welche Voraussetzungen dafür erfüllt sein müssen (zum Programmablauf siehe nächste Seite).

Die Tagung wird in Zusammenarbeit mit der Akademie für Technikfolgenabschätzung, Stuttgart, und der Europäischen Akademie Bad Neuenahr-Ahrweiler organisiert und aus Mitteln des BMBF gefördert. Die Tagung ist interdisziplinär ausgerichtet und richtet sich an Wissenschaftler aus den betroffenen Disziplinen, Entscheidungsträger aus Politik, Administration und Wirtschaft, an Nichtregierungsorganisationen und Interessenten in Medien und allgemeiner Öffentlichkeit.

Das ständig aktualisierte Programm ist auch von der Homepage des ITAS abrufbar unter: http://www.itas.fzk.de/v/03vwh/01.htm

Anmeldungen (Name, Institution und vollständige Anschrift) werden erbeten bis zum 30. April 2003 an:

\footnotetext{
Margareta Kullmann

Forschungszentrum Karlsruhe Institut für Technikfolgenabschätzung und Systemanalyse (ITAS)

Tel.: +49 (0) $7247 / 826346$

Fax: +49 (0) 7247 / 824806

E-Mail: kullmann@itas.fzk.de
} 


\title{
Symposium: Vom Wissen zum Handeln? Die Forschung zum Globalen Wandel und ihre Umsetzung Programmablauf
}

\section{Donnerstag, 3. Juli 2003}

\author{
10.30 Uhr Begrüßungskaffee und Registration \\ 11.00 Uhr Einführung \\ Prof. Dr. Manfred Popp \\ Forschungszentrum Karlsruhe
}
Sektion 1: $\quad$ Anforderungen der Nachhaltigkeit - Erwartungen an die Global Change Forschung Chair: Prof. Dr. Ortwin Renn TA-Akademie Stuttgart
11.30 - 12.00 Die Anforderungen an die Klimaforschung aus der Sicht der Politik Staatssekretär Wolf-Michael Catenhusen, BMBF
$12.00-12.30$ Die Erkenntnisse der Klimaforschung: Stellenwert und Aussagekraft für die Wirtschaft Joachim Hein, BDI
12.30 - 13.00 Klimaforschung und nachhaltige Politik: Die Wünsche der Umweltschutzorganisationen an die Klimaforscher Angelika Zahrnt, BUND und Nachhaltigkeitsrat der Bundesregierung (angefragt)
$13.00-13.30$ Klimaforschung und ihre Wirkung auf die übrigen Wissenschaften Hans-Olaf Henkel, Leibniz-Gemeinschaft
13.30 - 15.00 Mittagessen
Sektion 2: Was ist Gegenstand der Forschung zum Globalen Wandel? Chair: Prof. Dr. Peter Lemke Alfred-Wegener-Institut
15.00 - 15.45 Zukünftige Aufgabenfelder der Forschung zum Globalen Wandel Prof. Dr. Wolfram Mauser Universität München
15.45 - 16.30 Wissenschaftstheoretische Bemerkungen zu verschiedenen Formen des Holismus Prof. Dr. Michael Esfeld Universität Lausanne
$16.30-17.00$ Kaffeepause
17.00 - 17.45 Kann das Ganze Thema der Forschung sein? Prof. Dr. Carl Friedrich Gethmann Europäische Akademie Bad Neuenahr-Ahrweiler
18.00 Uhr Empfang und Abendessen Edelgard Bulmahn, Bundesministerin für Bildung und Forschung (angefragt)

Freitag, 4. Juli 2003

Sektion 3: $\quad$ Vom Wissen zum Handeln - das Beispiel des Klimawandels Chair: Prof. Dr. Armin Grunwald Forschungszentrum Karlsruhe

09.00 - 09.45 Warum die Lücke zwischen Wissen und Handeln in der Politik NICHT geschlossen werden kann Prof. Dr. Ulrich Steger International Institute for Management Development $(\mathrm{CH})$ (angefragt)

09.45 - 10.30 Praktische Erkenntnis: Vom Wissen zum Handeln Prof. Dr. Nico Stehr, Gotthard Bechmann Forschungszentrum Karlsruhe

10.30 - 11.15 Wann wird die Politik wach und wann wird sie handlungsbereit? Prof. Dr. Ernst Ulrich von Weizsäcker, MdB

$11.15-11.45$ Kaffeepause

\section{Abschlusspanel}

11.45 - 13.00 Forschung zum Globalen Wandel - Herausforderungen der nächsten Jahre 
13.00 Uhr Ende der Veranstaltung

\section{SEL-Stiftungsprofessur für in- terdisziplinäre Studien an TU Darmstadt mit Tagung abge- schlossen}

Mit der Tagung „Technikgestaltung zwischen Wunsch und Wirklichkeit. Interdisziplinäre Annäherungen“ am 24./25. Oktober 2002 in Darmstadt ging die SEL-Stiftungsprofessur von Prof. Dr. Armin Grunwald an der TU Darmstadt zu Ende. Etwa 60 Teilnehmer folgten den zehn Referaten in drei Sektionen und der abschließenden Podiumsdiskussion. Zurzeit ist die Publikation der Ergebnisse in Vorbereitung. Mit dem Erscheinen des Buches beim Springer-Verlag ist für Mai/Juni 2003 zu rechnen. Auf dem ITAS-Server und in der TA-TuP wird zu gegebener Zeit ein entsprechender Hinweis erscheinen.

》)

\section{Bericht über das Symposium „Technik für die Gesellschaft von morgen" von TAB und ITAS}

\section{Berlin, 22. November 2002}

In den Forschungslabors der Wissenschaften und der Industrie werden heute die Technologien entwickelt, die die Welt morgen bestimmen werden. Vorausschauende Entscheidungen in Politik und Wirtschaft entscheiden mit darüber, inwieweit die Chancen neuer Technologien für mehr Nachhaltigkeit, für eine wettbewerbsfähige Wirtschaft und für den Bedarf zukünftiger Märkte genutzt und inwieweit technikbedingte Risiken vermieden werden können. Zukunftsorientierte Technikentwicklung in Wissenschaft und Industrie geht in der TechnologieRegion Karlsruhe Hand in Hand mit einer entsprechenden Beratung von Politik und Gesellschaft.

Im Rahmen der Präsentation der TechnologieRegion Karlsruhe (TRK) vom 20. - 22. November 2002 in Berlin organisierten das Büro für Technikfolgen-Abschätzung beim Deutschen
Bundestag (TAB) und ITAS am 22.11. das Symposium „Technik für die Gesellschaft von morgen“. In vier Technologiefeldern wurde gezeigt, welche Entwicklungs- und Marktpotenziale in der TechnologieRegion Karlsruhe realisiert werden, welche Folgen dies für Gesellschaft und Wirtschaft haben wird und wie die Politik hierauf reagieren wird. Unter der abwechselnden Moderation von Prof. Dr. Armin Grunwald, Leiter von ITAS und TAB, und Dr. Horst Zajonc, Leiter der Wirtschaftsförderung der Stadt Karlsruhe, wurden folgende Themen in Form von Kurzreferaten und anschießender Diskussion behandelt:

Nanotechnologie - große Chancen in kleinen Dimensionen: Die Nanotechnologie hat innerhalb kurzer Zeit den Sprung an die Spitze der bekanntesten Entwicklungsrichtungen moderner Technik geschafft. Welche realistischen wirtschaftlichen und gesellschaftlichen Auswirkungen diese faszinierende Technologierichtung hat und welche möglichen Risiken drohen, war Thema der Diskussion. Referenten waren: Dr. Dagmar Oertel, TAB, und Axel E. Fischer, MdB.

Mit Sicherheit in das Informationszeitalter: Das Wirtschaftssystem hängt mittlerweile stark von einer funktionierenden Informationsinfrastruktur ab. Die Anfälligkeit von Informationsund Kommunikationstechnologien gegenüber technischem Versagen, aber auch gegenüber Missbrauch sind jedoch weithin bekannt. Mit welchen Strategien diesen Gefahren begegnet werden kann, war Thema des Podiums. Die Referenten waren: Prof. Dr. Gerhard Banse, ITAS; Jörg Tauss, MdB, und Dirk Fox, Fa. Secorvo, Karlsruher IT-Sicherheitsinitiative.

Roboter - Gehilfen oder Ersatz für den Menschen? Durch rasche Fortschritte in der Sensorik, in der Datenverarbeitung und in der Mechatronik ist der Einsatz von Robotern in vielen Bereichen des täglichen Lebens denkbar geworden. Der Einsatz von Robotertechnik in der Medizin, z. B. in Form von Prothesen oder in der Operationstechnik, aber auch wachsende Fähigkeiten der Industrieroboter werfen Fragen nach der Ersetzbarkeit des Menschen auf. Referenten waren: Dr. Michael Decker, Europäische Akademie Bad Neuenahr-Ahrweiler (jetzt ITAS); Prof. Dr. Rüdiger Dillmann, Universität Karlsruhe; Dr. Wolf Hartmut Prellwitz, IWKA. 
Energie für die Zukunft: Die Art und Weise der zukünftigen Nutzung von Energie entscheidet maßgeblich über viele Folgeprobleme, z. B. in Bezug auf die Belastung der Atmosphäre. Es wurden Optionen einer „nachhaltigen“ Energieversorgung diskutiert, zu denen einerseits erneuerbare Energien gehören, andererseits aber auch neue Energieumwandlungstechniken wie die Brennstoffzelle. Referenten waren: Dipl.-Phys. Torsten Fleischer, ITAS; Hans-Josef Fell, MdB; Dr. Wolfram Münch, EnBW.

(A. Grunwald)

।)

\section{Neue Veröffentlichungen}

\section{Gotthard Bechmann, Bettina-Johanna Krings, Michael Rader (eds.): Across the Divide. Work, Organization and So- cial Exclusion in the European Informa- tion Society. Berlin: Edition Sigma, 2003 (Gesellschaft - Technik - Umwelt, Neue Folge, 3), 270 S., 19,90 Euro, ISBN 3- 89404-933-2}

This volume provides an insight into the project „SOWING - Information Society, Work and the Generation of New Forms of Social Exclusion" which was performed on behalf of the European Commission from 1998 - 2000. The project united, apart from the Institute of Technology Assessment and Systems Analysis (ITAS), research groups from 7 European countries: Belgium, England, Finland (leading organisation), Ireland, Italy, Austria and Portugal. The articles in this volume are based on presentations at a conference which took place within the framework of the project in November 2000 at Karlsruhe Research Centre. The project's aim was to describe the informatisation of firms in the manufacturing and service industries in selected regions in these countries from a comparable perspective with respect to prevailing „technological practices“. This approach attempts to analyse structural and actor oriented moments of the use of information technologies on the level of the organisation and the level of the work processes in firms.
The project thus combined two research areas which so far have rarely been linked with each other: companies' restructuring processes based on modern ICT technology and their demand for related new skills and competencies, on the one hand, and risks of social exclusion on the other hand.

The analysis of the diffusion and the broad variety of application forms of ICTs and the empirical observation of corresponding changes inside enterprises and their social environment in the different countries involved in the project demonstrate that there is no single European path into the information society.

\section{Nico Stehr: Wissenspolitik. Die Über- wachung des Wissens. Frankfurt a. M.: Suhrkamp, 2003 (suhrkamp taschen- buch wissenschaft 1615), 327 S., 13,00 Euro, ISBN 3-518-29215-3}

Wir haben eine neue Phase in öffentlichen Auseinandersetzungen über die gesellschaftliche Rolle der Wissenschaften erreicht. Die kontroversen Diskussionen um embryonale Stammzellen, Neurogenetik, Xenotransplantationen oder reproduktives Klonen machen deutlich, dass die Frage nach den sozialen Voraussetzungen und Folgen ungebremst expandierender (natur)wissenschaftlicher Erkenntnisse zur dringenden Problematik der gesellschaftlichen Tagesordnung und des politischen Alltags wird. Nicht selten mündet diese Diskussion in den Ruf nach einer Überwachung und bewußten Steuerung des Wissens.

Doch welche Erkenntnisse sollen überwacht werden, wie sollen sie gesteuert werden, und wer ist verantwortlich? Und welches Wissen ist notwendig, um Wissen zu überwachen? Und in welchem Interesse wird entschieden? Werden wissenschaftliche Erkenntnisse (wieder) zu einem privaten Gut? Und wie organisiert man eine Überwachung des Wissens?

Dieses neue Feld der „Wissenspolitik“ wird die politische Landschaft verändern. Den Autor Nico Stehr interessieren ,die Grundlagen der unterschiedlichen Standpunkte in der Debatte zur Überwachung des Wissens wie auch die Wege und Chancen einer Regulierung des Wissens in modernen, und das heißt zunehmend: zerbrechlichen Gesellschaften". Stehr 
zeigt auf, dass trotz des „Herrschaftsverlustes der großen gesellschaftlichen Zweckorganisationen" die großen gesellschaftlichen Institutionen auch in diesem Kontext immer noch als handlungsfähige Systeme gesellschaftlicher Steuerung funktionieren.

)

\section{Personalia}

Zum Jahresbeginn 2003 wurden in ITAS drei neue Mitarbeiter eingestellt:

Dr. Michael Decker ist Physiker und war zuletzt wissenschaftlicher Mitarbeiter an der Europäischen Akademie zur Erforschung von Folgen wissenschaftlich technischer Entwicklungen in Bad Neuenahr-Ahrweiler GmbH. In ITAS arbeitet er mit in einer neuen Projektgruppe zur Technikfolgenabschätzung von Nanotechnologien (siehe Seite 169f. in diesem Heft) sowie im EU-Projekt TAMI (Technology Assessment in Europe. Between Method and Impact).

Auch Dr. Ulrich Fiedeler ist Physiker und gehört wie Michael Decker zur Projektgruppe Nanotechnologie. Er arbeitete zuletzt im Bereich Solarenergieforschung des Hahn-MeitnerInstituts in Berlin.

Dr.-Ing. Peter Proplesch ist Maschinenbauingenieur (Fachrichtung Verfahrenstechnik) und hat mehr als 20 Jahre im Industrieanlagengeschäft gearbeitet, u. a. im Bereich der Kohlevergasung und Gasaufbereitung. In ITAS ist er beteiligt am Projekt ,Systemanalyse (Technikfolgenabschätzung) zur Gaserzeugung aus Biomasse“.

Als Gastwissenschaftler kamen im Januar zu ITAS: Professor Dr. Andrzej Kiepas von der Schlesischen Universität Katowice in Polen sowie Prof. Dr. Frank Fischer von der Rutgers University.

Prof. Dr. Andrzej Kiepas ist Philosoph, Leiter des Lehrstuhls Philosophische Probleme heutiger Zivilisation und Direktor des Instituts für Philosophie der Schlesischen Universität Katowice. Sein wissenschaftliches Interesse gilt der Technikphilosophie in Verbindung mit der Philosophischen Anthropologie sowie der Wissenschafts- und Technikethik. Er war von
Anfang Januar bis zum 03. Februar 2003 im Rahmen einer Gastprofessur im ITAS tätig.

Prof. Dr. Frank Fischer ist Professor für Politische Wissenschaft an der Rutgers University, Newark and New Brunswick, New Jersey. Seine Forschungsinteressen umfassen u. a. Staatstheorie sowie Technologie-, Umweltund Wissenschaftspolitik. Während seines Gastaufenthalts bis August 2003 wird er sich u. a. beschäftigen mit der Analyse der institutionellen und legitimatorischen Probleme bei der Einführung gentechnisch hergestellter Nahrungsmittel, mit Problemen der Institutionalisierung von partizipatorischem Technology Assessment und der Evaluierung von Umweltpolitiken.

Bei ITAS ausgeschieden sind Andreas Arlt und Maren Heinke.

Bereits Ende November 2002 hat Andreas Arlt ITAS verlassen. Er war beteiligt am Projekt zur Energetischen Nutzung biogener Abfälle bzw. Nachwachsender Rohstoffe und promovierte dort über das Thema „Systemanalytischer Vergleich zur Herstellung von Ersatzbrennstoffen aus biogenen Abfällen am Beispiel von kommunalem Klärschlamm, Bioabfall und Grünabfall“. Seit Dezember 2002 ist er „Junior Professional Officer" im Interim Sekretariat der Stockholm Konvention „Persistente Organische Schadstoffe" (Persistant Organic Pollutants, POP) bei der UNO bzw. dem United Nations Environment Programme (UNEP) in Genf.

Mitte Februar hat Dr. Maren Heincke ITAS verlassen. In den letzten zwei Jahren arbeitete sie im HGF-Verbundprojekt „Global zukunftsfähige Entwicklung - Perspektiven für Deutschland“ im Aktivitätsfeld „Ernährung und Landwirtschaft". Maren Heincke wechselt zu der Berlin-Brandenburgischen Akademie der Wissenschaften nach Berlin. Sie wird dort Wissenschaftliche Mitarbeiterin im Projekt „Gentechnologiebericht". 